\title{
STANDAR PENDIDIKAN ISLAM DAN STANDAR PROSES PADA ANAK DALAM QS. LUQMAN (31):12-19 DAN QS. AL-KAHFI (18): 60-82
}

\section{ISLAMIC EDUCATIONAL STANDARDS AND STANDARDIZED PROCESSES IN CHILDREN QS. LUQMAN (31): 12-19 AND QS. AL-CAVE (18): 60-82}

\author{
A Sugiana ${ }^{1 \mathrm{a}}$ \\ 1 Program Pascasarjana, Program Studi Agama Islam, Fakultas Ilmu Tarbiyah dan Keguruan, \\ Universitas Islam Negeri Sunan Kalijaga Yogyakarta, Jalan Laksda Adisucipto, Caturtunggal, \\ Kecamatan Depok, Kabupaten Sleman, Daerah Istimewa Yogyakarta \\ a Korespondensi: Aset Sugiana, Email: asetsugiana@gmail.com \\ (Diterima: 15-09-2018; Ditelaah: 16-09-2018; Disetujui: 31-10-2018)
}

\begin{abstract}
This research aims to describe the standards of Islamic education and the standards process in QS. Luqman (31): 12-19 and QS. Al-Cave (18): 60-82. This research method used library research to be analyzed or concluded. Research data obtained from the results of the recording of Islamic values that are found in the QS. Luqman (31): 12-19 and QS. Al-Cave (18): 60-82. The steps of procurement data include: (1) the determination of the standard of Islamic education and standards process contained in the QS. Luqman (31): 12-19 and QS. Al-Cave (18): 60-82; (2) record-keeping; and (3) the determination of the unit. The validity of the data is discussed and consulted on data findings to experts and peers. Technique of data analysis used ie classifies, combine, interpret, and conclude. Research results in QS. Luqman (31): 12-19 and indicates that there are educational standards, namely: (1) whence are education; (2) education dedicated to both parents; (3) education of discipline and obedience of the law; (4) private education independent and responsible; and (5) education akhlaqul karimah. And the standards process in respect of QS. Al-Cave (18): 60-82, namely: (1) the value of patience and determined; (2) the value of the urgenitas prepare; (3) tawadhu' attitude; and (4) the value of the urgency to explain the subject matter.
\end{abstract}

Keywords: Islamic education standards, standards process, QS. Luqman (31): 12-19, QS. AlCave (18): 60-82.

\section{ABSTRAK}

Penelitian ini bertujuan untuk mendeskripsikan standar pendidikan Islam dan standar proses dalam QS. Luqman (31):12-19 dan QS. Al-Kahfi (18):60-82. Metode penelitian ini adalah menggunakan penelitian kepustakaan yang akan dianalisis atau disimpulkan. Data penelitian diperoleh dari hasil pencatatan nilai-nilai keislaman yang ditemukan dalam QS. Luqman (31): 12-19 dan QS. Al-Kahfi (18): 60-82. Langkah-langkah pengadaan data meliputi: (1) penentuan standar pendidikan Islam dan standar proses yang terdapat dalam QS. Luqman (31): 12-19 dan QS. Al-Kahfi (18): 60-82; (2) pencatatan; dan (3) penentuan satuan unit. Keabsahan data didiskusikan dan dikonsultasikan penemuan-penemuan data kepada para ahli dan teman sebaya. Teknik analisis yang peneliti gunakan yaitu mengklasifikasikan, menggabungkan, menafsirkan, dan menyimpulkan. Hasil penelitian dalam QS. Luqman (31): 12-19 menunjukkan bahwa terdapat standar pendidikan, yaitu: (1) pendidikan ketauhidan; (2) pendidikan berbakti kepada kedua orang tua; (3) pendidikan disiplin dan taat terhadap hukum; (4) pendidikan pribadi mandiri dan bertanggung jawab; dan (5) pendidikan akhlaqul karimah. Dan standar proses dalam QS. Al-Kahfi (18): 60-82, yaitu: (1) nilai kesabaran dan 
tekat; (2) nilai urgenitas menyiapkan bekal; (3) sikap tawadhu'; dan (4) nilai urgensi menjelaskan materi pelajaran.

Kata kunci: standar pendidikan Islam, standar proses, QS. Luqman (31): 12-19, QS. Al-Kahfi (18): 60-82.

Sugiana, A. (2018). Standar Pendidikan Islam dan Standar Proses pada Anak dalam Qs. Luqman (31):12-19 dan Qs. Al-Kahfi (18): 60-82. Tadbir Muwahhid, 2(2), 156-166.

\section{PENDAHULUAN}

Al-Qur'an merupakan kitab suci umat Islam memiliki berbagai varian pesan untuk mengajak pembacanya mengindahkan, membaca, dan bahkan meneladani isi yang dikandungnya. Kisah dan cerita memiliki daya pikat dalam mentransformasikan nilai kebaikan dan keluhuran dari makna kehidupan. Cerita tidak hanya berdiri untuk dirinya atau makna tanpa yang ingin dicapai. Cerita juga bukan hanya bertujuan mengingat kejadian yang telah berlalu untuk diingat sebagai memori. Namun, cerita mememiliki kemampuan menyampaikan pesan yang tidak bisa dicapai dengan kalimat perintah atau larangan (Arifin, 2018).

Al-Qur'an menyampaikan pelajaran kepada manusia melalui berbagai kisah khususnya dalam dunia pendidikan. AlQur'an menyampaikan pesan melalui kisah Luqman yang mendidik anaknya. Kisah Musa dengan Khidir yang menceritakan hubungan guru dengan murid, tentunya akan memberikan pesan nilai-nilai pendidikan Islam, standar proses, dan menjadi contoh dalam pembelajaran yang lebih baik lagi.

Berdasarkan teori dan fakta permasalahan yang ada dapat disimpulkan, yang akan menjadi titik fokus dalam penelitian ini adalah bagaimana Standar Pendidikan Islam dan Standar Proses pada Anak dalam QS. Luqman (31): 12-19 dan QS. Al-Kahfi (18): 60-82.

\section{MATERI DAN METODE}

Jenis penelitian ini adalah penelitian kepustakaan atau library research. Penelitian kepustakaan atau library research merupakan cara memperoleh data-data dan bahan-bahan yang peneliti perlukan dalam menyelesaikan penelitian. Data-data tersebut diperoleh dari perpustakaan berupa buku, ensklopedia, KBBI (Kamus Besar Bahasa Indonesia), jurnal pendidikan, dokumen-dokumen, dan lain sebagainya (Harahap, 2014).

Waktu penelitian ini sendiri dilaksanakan pada tanggal 02 Maret - 17 April 2018. Penelitian ini adalah penelitian kepustakaan atau (library research), maka tempat penelitian dilakukan di perpustakaan. Sedangkan subjek dalam penelitian adalah peran para guru yang akan mengajar dan nantinya akan menyampaikan materi pelajaran, dan peserta didik, supaya standar pendidikan tercapai.

Teknik pengumpulan data yang peneliti gunakan adalah pengumpulan data literatur yaitu mengumpulkan semua data/bahanbahan pustaka yang saling berhubungan dengan sasaran yang diteliti. Jadi penelitian kepustakaan disini adalah studi teks yang semuanya dianalisis serta disimpulkan dengan toeritis (Muhadjir, 2000).

Metode analisis data adalah teknik penelitian yang digunakan untuk membuat kesimpulan-kesimpulan yang sesuai dengan data atau valid, dengan tetap memperhatikan pada konteksnya. Strategi 
analisis yang digunakan adalah dengan memfokuskan pada intrepretasi data kontekstualisasi atas data yang berhubungan dengan standar pendidikan dan standar proses dalam Al-Qur'an, sehingga memperoleh kesimpulan dari sebuah ide-ide dan teori-teori. Penelitian ini bertujuan supaya mengetahui apa saja halhal yang tersirat dalam Al-Qur'an khususnya QS. Luqman (31): 12-19 dan QS. Al-Kahfi (18): 60-82, dan untuk menyusun perkembangan serta mengefektifkan dan mengefisienkan proses kegiatan belajar mengajar antara guru dan peserta didik.

\section{HASIL DAN PEMBAHASAN}

\section{Hasil}

Hasil tentang analisis Standar Pendidikan Islam dalam QS. Luqman (31): 12-19 serta Standar Proses dalam QS. Al-Kahfi (18): 6082 diuraikan pada Tabel 1.

Tabel 1 Analisis standar pendidikan islam dalam QS. Luqman dan standar proses dalam QS. Al-Kahfi

\begin{tabular}{ll}
\hline Standar & Pendidikan ketauhidan, \\
Pendidikan & Pendidikan berbakti \\
Islam dalam & kepada kedua orang \\
QS. Luqman & tua, Pendidikan disiplin \\
(31): 12-19 & dan taat terhadap \\
& hukum, Pendidikan \\
& pribadi mandiri dan \\
& bertanggung jawab, dan \\
& Pendidikan akhlaqul \\
& karimah. \\
Standar & Nilai kesabaran dan \\
Proses dalam & tekat, Nilai urgenitas \\
QS. Al-Kahfi & menyiapkan bekal, \\
(18): 60-82 & Sikap tawadhu', dan \\
& Nilai urgensi \\
& menjelaskan materi \\
& pelajaran. \\
\hline
\end{tabular}

\section{Pembahasan}

\section{Standar Pendidikan Islam QS. Luqman} (31): 12-19

Pengertian secara umum mengenai QS. Luqman: 12 adalah, sesudah Allah menjelaskan kerusakan aqidah orang-orang musyrik, karena mereka telah mempersekutukan hal-hal yang tidak dapat menciptakan sesuatu dengan Tuhan yang menciptakan segala sesuatu, dan setelah Dia menjelaskan bahwa orang musyrik itu adalah orang yang zalim lagi tersesat. Bumi dan semuanya menunjukkan kepada keesan-Nya. Dan sesungguhnya Allah telah memberikan hal tersebut kepada sebagian hamba-hamba-Nya seperti Luqman, yang mana hal-hal itu telah tertanam secara fitrah di dalam dirinya, tanpa ada seorang nabi pun yang membimbingnya, dan pula tanpa seorang rasul pun yang diutus kepadanya (Al-Maragi, 1992).

Disamping itu, Luqman selalu mencintai kebaikan untuk manusia serta mengarahkan semua anggota tubuhnya sessuai dengan bakat yang diciptakan untuknya. Metode pendidikan anak yang disampaikan Luqman dalam mendidik anak adalah metode suri tauladan. Luqman berwasiat kepada anaknya selalu memberikan contoh-contoh langsung yang dilakukan oleh Luqman yakni dengan perbuatan nyata yang diperlihatkan (dicontohkan) kepada anaknya (Sada, 2015). Selanjutnya dalam QS. Luqman (31): 13, Luqman memberikan penjelasan kepada anaknya, bahwa jangan sekali-kali menyekutukan Allah, karena sama halnya kita menduakan atau menyamakan Allah dengan yang lain, karena menduakan Allah adalah suatu kedzaliman yang besar. Adapun pendidikan Islam tersebut dalam Sada (2015) di antaranya: 


\section{Pendidikan ketauhidan dalam QS. Luqman (31): 13}

Pendidikan tauhid sudah seharusnya diberikan kepada anak, supaya anak mengetahui siapa yang menciptakannya dan selalu taat kepada Allah SWT. Sejak dilahirkan anak sudah dikenalkan dengan Sang Khalik, dengan mengumandangkan azan, sebagai pendidikan utama dan pertama setelah lahir di dunia (Al-Maragi, 1992); (2) Pendidikan berbakti kepada kedua orang tua dalam QS. Luqman (31): 14. Perintah Allah sangat jelas memerintahkan manusia berbakti kepada orangtuanya, dengan mencontoh serta melaksanakannya.

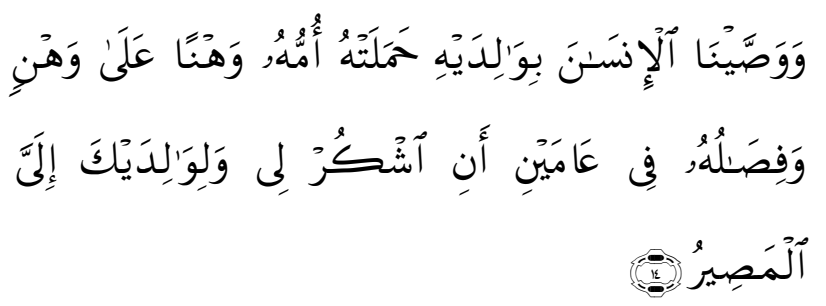

Artinya: Dan Kami perintahkan kepada manusia (agar berbuat baik) kepada dua orang tuanya. Ibunya telah mengandungnya dalam keadaan lemah yang bertambahtambah, dan menyapihnya dalam dua tahun. Bersyukurlah kepada-Ku dan kepada kedua orang tuamu, hanya kepada Aku kembalimu. (QS. Luqman (31): 14) (Al-Qur'an dan Terjemahan, 2009).

Maksud derita ibu waktu mengandung bukan semakin berkurang, malah sebaliknya semakin bertambah. Sebab beban kandungan kian lama kian membesar dan memberat. Di waktu melahirkan pun sang ibu menyabung nyawa, sedang sang ayah sibuk berusaha mencari nafkah. Setelah sang bayi lahir, sebenarnya derita ibu belum berakhir, sebab masih harus mengurus dan menyusukan bayinya sampai masa penyapihan lebih kurang dua tahun. Oleh karena itu, berbaktilah kepada orang tuamu, sebab merekalah yang menjadi penyebab kehadiranmu di muka bumi ini.
Selanjutnya, bersyukurlah kepada Allah, sebab Dia-lah yang menciptakanmu, yang memberi rezeki, dan kepada-Nya pula kamu akan kembali (Surin, 2012).

QS. Luqman pada ayat 14 menyebutkan tentang sebab diperintahkan harus berbuat baik kepada ibu, yaitu:

"Ibu mengandung dan melahirkan"

Semasa mengandung ibu dengan sabar menahan penderitaan yang berat, sejak awal bulan pertama, hingga kandungannya semakin lama semakin berat, dan ibu merasa semakin lemah, kemudian melahirkan.

"Ibu menyusui anaknya hingga sampai masa kurang lebih dua tahun"

Banyak penderitaan dan kesulitan dialami ibu dalam masa menyusui anak. Hanyalah Allah yang mengetahui segala penderitaan (Al-Maragi, 1992).

\section{Pendidikan disiplin dan taat terhadap hukum dalam QS. Luqman (31): 16}

Character building dan basic personality anak dilakukan melalui penanaman disiplin yang tinggi, agar anak memiliki kekuatan jiwa, atau mental yang tinggi, tidak mudah menyerah dengan keadaan. Dan anak dilatih untuk taat terhadap hukum yang berlaku, anak didik mengenal rewad and punishment (ganjaran dan hukuman), agar anak memiliki tanggung jawab terhadap apa saja yang ia kerjakan dan lakukan, baik dalam bentuk ucapan dan perbuatan (Sada, 2015).

\section{Pendidikan pribadi mandiri dan bertanggung jawab dalam QS. Luqman} (31): 17

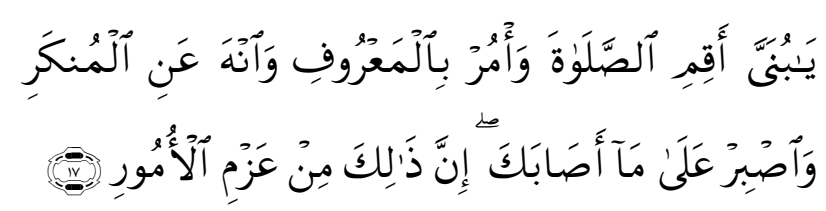

Artinya: Wahai anakku! laksanakan shalat dan suruhlah (manusia) berbuat yang makruf dan cegahlah (mereka) dari yang 
mungkar dan bersabarlah terhadap apa yang menimpamu, sesungguhnya yang demikian itu termasuk perkara yang penting. (QS. Luqman (31): 17) (Al-Qur'an dan Terjemahan, 2009).

Hai anakku, dirikanlah shalat, yakni kerjakanlah shalat dengan sempurna sesuai dengan cara yang diridai. Karena di dalam shalat itu terkandung rida Tuhan, sebab orang yang mengerjakannya berarti menghadap dan tunduk kepada-Nya, dan di dalam shalat terkandung pula hikmat lainnya, yaitu dapat mencegah orang yang bersangkutan dari perbuatan keji dan mungkar (Al-Maragi, 1992).

Luqman mendidik anaknya untuk menjadi manusia berkepribadian mandiri serta bertanggung jawab terhadap profesi. Berikut adalah tiga proses yang diajarkan oleh Luqman terhadap anaknya: (1) Agar anaknya tekun melaksanakan shalat, sebagaimana tanggungjawabnya sebagai makhluk individu; (2) Diperintahkan untuk shalat pada umur tujuh tahun dan pukullah pada umur sepuluh tahun. Bukan berarti Luqman baru berbicara tentang shalat ketika anak sudah berumur tujuh tahun, tetapi jauh sebelum itu anak telah dididik untuk shalat; dan (3) Anak yang sudah dewasa dan mandiri bertanggung jawab sebagai makhluk sosial, untuk belajar dalam masyarakat sekitarnya, artinya diharapkan menjadi pemimpin bagi orang yang bertaqwa kepada Allah (Al-Maragi, 1992).

\section{Pendidikan akhlaqul karimah dalam QS. Luqman (31): 18}

Dan janganlah kamu memalingkan wajah dari manusia (karena sombong) Akan tetapi berjalanlah dengan sikap sederhana karena sesungguhnya cara jalan yang demikian mencerminkan rasa rendah diri, sehingga pelakunya akan sampai kepada semua berkah (Al-Maragi, 1992).
Adapun tanda-tanda seseorang bersifat sombong atau angkuh yaitu: (1) Bila bertemu dengan orang lain baik kenal ataupun tidak dia tidak mau bertegur sapa, bahkan cenderung tidak ramah; (2) Kemudian berjalan dengan gaya yang angkuh, seakan-akan jalan hanya miliknya sendiri tanpa memikirkan pengguna jalan lainnya (Sada, 2015).

Berdasarkan uraian tersebut bahwa banyak sekali terdapat nilai-nilai pendidikan dan standar pendidikan Islam yang bisa menjadi pelajaran dan sebagai metode dalam mengajar dan memotivasi supaya senantiasa berbuat kebaikan, dan menjauhi segala perbuatan yang tidak baik (tidak ramah) terhadap orang lain.

Standar Proses QS. Al-Kahfi (18): 6082

Nilai dalam Al-Qur'an adalah media yang bertujuan untuk menyampaikan pesan keessan Allah, kebaikan, dampak prilaku buruk, kebenaran, dan moral yang agung. Kisah bertemunya Musa dan Khidir banyak dimaknai bertemunya dua pengetahuan yang berbeda, Musa berpikir dengan pemahaman syariat, sedangkan Khidir melakukan berdasarkan pemahaman hakikat (Arifin, 2018).

Terdapat nilai pendidikan dan internalisasi nilai-nilai dalam kisah Musa dan Khidir. Nilai-nilai tersebut perlu dimiliki oleh guru ataupun murid saat sedang mengajar bagi guru dan belajar bagi sang murid. Dialog yang terjadi di antara keduanya mengandung nilai pembelajaran, yaitu terbangunnya proses belajar atau transper ilmu pengetahuan sesuai tujuan yang telah ditentukan (Arifin, 2018).

Sebab kisah ini adalah sebagaimana yang diriwayatkan dari Nabi Saw yang terdapat dalam Bukhari dan Muslim. Pada suatu hari Musa A.S. duduk di tempat Bani Israil. 
Begitu dia menyampaikan ceramah dengan sangat baik, ada yang bertanya kepadanya, "Apakah kamu mengetahui seorang pun yang lebih berpengetahuan dari pada kamu?" Dia menjawab, "Tidak ada." Kemudian Allah SWT mewahyukan kepadanya, "Tentu ada, yaitu hamba Kami, Khidir." Musa berkata, "Wahai Tuhanku, tunjukkan kepadaku jalan untuk dapat bertemu dengannya." Kemudian Allah SWT mewahyukan kepadanya agar berjalan disepanjang pantai hingga sampai tempat pertemuan antara dua laut. Begitu ikan hilang, maka disitulah tempatnya. Musa pun melakukan itu dan berkata kepada pembantunya sebagai penegasan untuk melaksanakan tekadnya (Zuhaili, 2013).

Nilai-nilai pendidikan tersebut menurut Arifin (2018) terurai dalam poin berikut:

1. Nilai kesabaran dan tekat dalam QS. AlKahfi (18): 60

Peristiwa terjadi ketika Musa menyampaikan dakwah kepada kaumnya, lalu ditanya oleh kaumnya. "Adakah orang yang lebih pandai darimu?" "Tidak ada," jawab Musa. Oleh karena itulah Allah mendidik melalui peristiwa yang terlihat ganjil sehingga ia menyadari bahwa di atas orang pandai ada yang lebih pandai. Dalam al-Qur'an disebutkan bahwa Musa dengan tekad dan kesabaran akan melakukan perjalanan menemui orang yang lebih pandai daripada dirinya (Arifin, 2018).

Keinginan Musa untuk menemukan tempat Khidir ditempuh selama bertahuntahun. Sebuah perjalanan yang membutuhkan waktu dan tenaga. Secara implisit, cerita ini mengisyaratkan akan kegigihan Musa untuk berguru kepada Khidir. Selain itu kesabaran yang dapat dipelajari dari Musa, dapat pula di ambil dari Khidir. Berbagai perbuatan yang dilakukan Musa yang berpaham syar'i, yang tidak sabar dan selalu menanyakan segala perbuatan beliau, tetapi tetap mengizinkan Musa untuk berguru kepadanya (Arifin, 2018).

2. Nilai urgenitas menyiapkan bekal dalam QS. Al-Kahfi (18): 62-64

Bagi para pencari ilmu maka diperlukan bekal untuk mendapatkan ilmu tersebut. Diantara bekal yang dibutuhkan dalam mencari ilmu adalah kebutuhan makan dan minuman yang dapat memperkuat fisik dan tenaganya (Arifin, 2018). Musa berkata kepada pembantunya dalam QS. Al-Kahfi (18): 62-64 yang berbunyi:

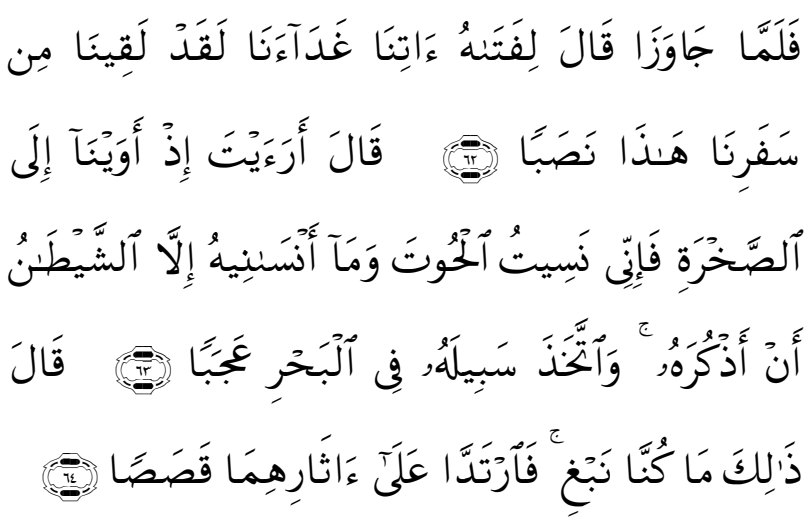

Artinya: 62. Maka ketika mereka telah melewati (tempat itu), Musa berkata kepada pembantunya, "Bawalah kemari makanan kita; sungguh kita telah merasa letih karena perjalanan kita ini". 63. Dia (pembantunya) menjawab, "Tahukah engkau ketika kita mecari tempat berlindung di batu tadi, maka aku lupa untuk (menceritakan tentang) ikan itu dan tidak ada yang membuat aku lupa untuk mengingatnya kecuali setan, dan (ikan) itu mengambil jalannya ke laut dengan cara yang aneh sekali". 64. Dia (Musa) berkata, "Itulah (tempat) yang kita cari." lalu keduanya kembali, mengikuti jejak mereka semula. (QS. Al-Kahfi(18): 6264) (Al-Qur'an dan Terjemahan, 2009: 301).

Begitu Musa dan pembantunya sampai di pertemuan dua laut, tempat pertemuan dengan hamba yang soleh, keduanya lupa ikan yang mereka bawa lantaran ikan itu hidup kembali dan menghilang dengan 
menyusuri jalannya di air. Ini merupakan hal yang sangat aneh bagi Musa dan pembantunya. Kembalinya ikan menjadi hidup lagi merupakan mukjizat Musa ketika Musa dan pembantunya Yusya' melampaui tempat pertemuan dua laut, yaitu tempat mereka berdua lupa terhadap ikan, dan keduanya terus berjalan selama satu hari siang dan malam, dan pada keesokan harinya Musa merasa lapar, maka dia berkata kepada pembantunya, "Bawalah kemari makanan kita, perjalanan ini benarbenar membuat kita lelah." Pembantunya menjawab, "Tahukah engkau, maksudnya beritahukan kepadaku mengenai apa yang terjadi padaku, saat kita berlindung di batu besar di tempat pertemuan dua laut? Aku lupa memberitahukan kepadamu mengenai apa yang terjadi terkait kisah ikan. Ikan itu bergerak-gerak lantas menjadi hidup kembali dan terjatuh ke laut. Tidak ada yang membuatku lupa menyebutkan itu selain setan, dan ikan mengambil jalannya di laut dengan aneh" (Zuhaili, 2013).

Kalimat "bawalah kemari makanan kita" mengajarkan kepada siapapun yang mengadakan perjalan (mencari ilmu) perlu menyiapkan bekal, selain tetap harus senantiasa berserah tawakkal kepada Allah SWT.

3. Nilai Tawadhu' dalam QS. Al-Kahfi (18): 65-66
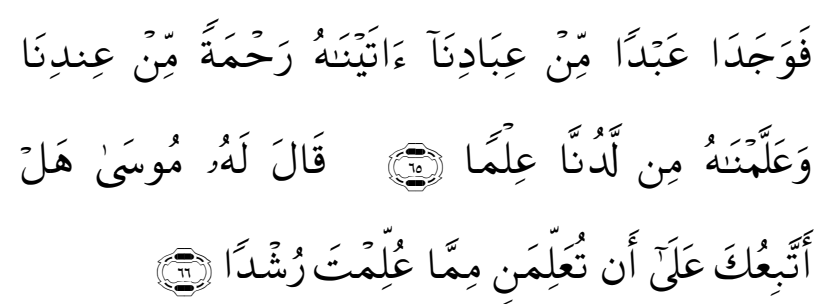

Artinya: 65. lalu mereka berdua bertemu dengan seorang hamba di antara hambahamba Kami, yang telah Kami berikan rahmat dari sisi Kami, dan yang telah Kami ajarkan ilmu kepadanya dari sisi Kami. 66. Musa berkata kepadanya, "Bolehkah aku mengikutimu agar engkau mengajarkan kepadaku (ilmu yang benar) yang telah diajarkan kepadamu (untuk menjadi) petunjuk?" (QS. Al-Kahfi (18): 65-66 (AlQur'an dan Terjemahan, 2009).

Musa berkata, "Inilah yang kita cari, karena ini berarti tanda kita berhasil sampai di tempat yang dituju." Keduanya pun kembali menyusuri jalan yang telah mereka lalui dengan mengikuti jejak telapak kaki mereka. Kemudian keduanya menemukan di dekat batu besar yaitu tempat pertemuan dua laut seorang hamba yang soleh dari hamba-hamba Allah, yaitu Khidir. Musa memberi salam kepadanya (Zuhaili, 2013).

Sikap tawadhu' Musa yang bersedia belajar kepada Khidir seharusnya terpatri dalam diri pembelajar, karena dengan memiliki sikap tawadhu' akan memudahkan seseorang menerima ilmu pengetahuan dari orang lain. Orang tawadhu' adalah ia yang selalu respek dan menerima kebenaran dari orang lain. Orang tawadhu' adalah ia yang selalu respek dari kebenaran dari orang lain. Dengan kata lain tawadhu' merupakan sikap seseorang tidak memandang dirinya memiliki nilai lebih dulu dibandingkan orang lain. Selain itu, sikap Musa memohon kepada Khidir adalah bentuk etika seorang murid yang hendak belajar kepada gurunya (Arifin, 2018).

4. Nilai urgensi menjelaskan materi pelajaran dalam QS. Al-Kahfi (18): 78-82

Setelah suatu perjanjian atau kontrak antara Nabi Musa dan Hamba Allah, bahwa Nabi Musa tidak boleh menanyakan apapun kepada hamba Allah kecuali sudah ada penjelasan tentang hal tersebut. Dalam perjalanan, ujian yang sulit bagi Musa untuk mengetahui sejauh mana kesabarannya dalam menghadapi apa-apa yang dilakukan oleh hamba yang soleh, Khidir, terjadi tiga peristiwa yang aneh, tidak selaras dengan pokok-pokok pengetahuan dan syariat yang 
dianut Musa, yang membuat Musa tidak dapat menerima setiap kejadian darinya, seraya melupakan perjanjian yang telah disepakatinya dengan Khidir (Zuhaili, 2013).

Terdapat tiga kisah/kejadian saat dalam perjalanan Musa dan Khidir, yaitu:

1) Kisah perahu dalam QS. Al-Kahfi (18): 71-73

Ketika perahu sedang berlayar membawa mereka di tengah gelombang laut, Khidir melubangi perahu dengan kapak hingga satu papannya terlepas, kemudian dia menambalnya. Dengan nada penolakan Musa berkata kepada Khidir, “Apakah kamu melubanginya untuk menenggelamkan penumpangnya? Sungguh kamu telah melakukan suatu kemungkaran yang besar. Khidir berkata kepada Musa, "Bukankah aku telah mengatakan kepadamu sebelum ini bahwa kamu tidak akan sanggup bersabar denganku atas perbuatan yang kamu lihat kepadaku." Musa pun meminta maaf kepada Khidir seraya berkata, "Janganlah kamu menghukumku lantaran kelupaanku, dan lantaran aku mengabaikan pesanmu pada saat pertama kali, dan jangan membebaniku perkara yang sangat sulit bagiku" (Zuhaili, 2013).

2) Kisah anak muda dalam QS. Al-Kahfi (18): 74-76

Kisah anak muda, kisah ini terjadi setelah Musa, pembantunya, dan Khidir keluar dari perahu. Saat Musa dan Khidhr berjalan di pantai, Khidhir melihat seorang anak muda yang bersih, tampan dan belum baligh sedang bermain dengan anak-anak lain. Ternyata Khidir membunuh anak itu dengan memenggal kepalanya. Musa pun berkata, apakah kamu membunuh jiwa yang bersih dari dosa tanpa alasan? Sunggu kamu telah melakukan suatu kemungkaran. Khidir pun menjawabnya, "Bukankah aku telah mengatakan kepadamu bawa kamu tidak akan sanggup menahan diri dari apa yang aku lakukan, dan kamu tidak akan diam terhadap aku yang aku perbuat. Kemudian sekali lagi Musa meminta maaf (az-Zuhaili, 2013).

3) Kisah dinding rumah dalam QS. Al-Kahfi (18): 77

Selanjutnya tentang bagaimana perjalanan Musa dan Khidir. Kisah dinding rumah yaitu Musa dan Khidir berjalan sesudah terjadi dua kejadian sebelumnya, hingga begitu keduanya sampai di suatu negeri, keduanya meminta kepada penduduknya untuk menjamu keduanya dan memberi makan untuk menghilangkan kelaparan mereka. Namun penduduk negeri itu tidak berkenan menjamu. Kemudian di negeri tersebut Musa dan Khidir menemukan dinding yang hendak roboh. Khidir pun menegakkan kembali seperti semula. Musa berkata kepada Khidir, "Andai berkenan maka kamu dapat meminta imbalan atas perbaikan dinding, karena penduduk negeri ini tidak berkenan menjamu kita, maka mereka tidak berhak atas pekerjaan secara cuma-cuma." Khidir menjawabnya, "Pemungkiran atau protes yang ketiga ini adalah sebab perpisahan di antara kita, sesuai dengan perjanjian, dan aku akan memberitahukan kepadamu penjelasan terkait sebab perbuatanperbuatan yang kamu pungkiri padaku, dan kamu tidak bersabar terhadapnya, yaitu pelubangan perahu, pembunuhan anak muda belia dan perbaikan dinding (Zuhaili, 2013).

Nabi Musa sadar bahwa dia telah melakukan dua kali kesalahan, akan tetapi tekadnya yang kuat untuk meraih makrifat mendorongnya bermohon agar diberi kesempatan terakhir. Untuk itu, dia berkata, "jika aku bertanya kepadamu, wahai saudara dan temanku, tentang sesuatu 
sesudah kali ini, maka janganlah engkau menjadikan aku temanmu dalam perjalanan ini lagi, yakni aku rela, tidak kecil hati, dan bisa mengerti jika engkau tidak menemaniku lagi. Sesungguhnya engkau telah mencapai batas yang sangat wajar dalam memberikan uzur padaku karena setelah dua kali aku melanggar dan sudah dua kali pula engkau memaafkanku" (Shihab, 2006).

Sebagai guru seharusnya berkenan menjelaskan materi yang diberikan kepada anak didik sehingga paham. Tidak semua murid ketika menerima materi pelajaran dapat memahami secara bersamaan dengan murid yang lain. Oleh karena itu, upaya pengulangan menjadi penting untuk menjadikan mereka paham pelajaran yang diterima (Arifin, 2018).

Guru tidak boleh bosan apabila memang murid selalu bertanya, bisa jadi memang level tingkat pemahaman mereka lambat sehingga membutuhkan penjelasan lanjutan. Penjelasan yang dipaparkan Khidir kepada Musa melambangkan upaya seorang guru menjelaskan kepada murid terkait materi yang dipelajari. Dia jelasakan mengapa Khidir melubangi perahu, membunuh seorang anak muda dan menegakkan dinding rumah yang hampir roboh (Arifin, 2018).

Berikut penjelasan sebab-sebab yang dilakukan oleh Khidir selama dalam perjalanan, yaitu:

Alasan mengapa dia (Khidir) melubangi perahu dalam QS. Al-Kahfi (18): 78-79

Adapun kejadian pelubangan perahu, itu dimaksudkan untuk membuat perahu tampak jelek demi menjaga dan melindunginya, Sesungguhnya Allah telah menunjukkan Khidhr kepada hikmah batiniah. Maka dia berkata, sesungguhnya aku melubangi perahu tersebut karena perahu itu akan melintasi seorang raja yang zalim, yang akan merampas tiap-tiap perahu yang masih bagus. Aku merusaknya agar raja tidak merampasnya, karena jelek. Dengan demikian, perahu ini masih dapat dimanfaatkan para pemiliknya yang miskin itu, yang tidak memiliki barang berharga selain perahu itu (Rifa'i, 2012).

Dia (Khidir) menjelaskan alasan mengapa membunuh anak muda (kafir) dalam QS. AlKahfi (18): 80-81

Adapun kejadian terkait pembunuhan terhadap anak muda, yaitu karena dia kafir, sementara kedua orang tuanya yang beriman menyukainya, maka ada kekhawatiran bahwa anak ini akan diikuti dalam kekafiran dan keterjerumusan dalam kezaliman dan kedurhakaan, yaitu saat dia sudah dewasa, karena kecintaan terhadap anak merupakan naluri dan dimungkinkan terjadi sikap yang toleran dan simpati dari kedua orang tuanya kepadanya. Dengan demikian, pembunuhan terhadapnya merupakan perlindungan terhadap akidah kedua orang tuanya. Ini termasuk dalam kategori antisipasi, maksudnya mencegah sarana yang berimplikasi pada perbuatan terlarang menurut syariat (Zuhaili, 2013).

Dia (Khidir) pun menjelaskan alasan menegakkan dinding yang hampir roboh dalam QS. Al-Kahfi (18) :82

Adapun terkait pembangunan dinding tanpa imbalan, itu terjadi di Negeri Anthakiyah. Dinding rumah tersebut hampir roboh dan dibawahnya tersimpan harta yang disimpan milik dua anak yatim di kota itu. Sementara ayah mereka berdua adalah orang yang soleh, maka Allah hendak menjaga harta itu tetap tersimpan dan terjaga bagi keduanya. Oleh karena itu, Khidhr meruntuhkan kemudian membangun kembali untuk menjaga harta kedua anak yatim tersebut. Setelah mengetahui sebab-sebab perbuatan itu dan 
mengetahui hikmahnya, hati Musa menjadi tenang kembali dan kemarahannya pun reda, serta hilanglah gejolak di dalam dirinya yang memandang penting penolakan terhadap kemungkaran secara zahir, karena Allah memberi taufik kejalan yang lurus (Zuhaili, 2013).

Penjelasan yang diuraikan Khidir menjadikan Musa menjadi pembelajar yang paham atas materi yang diterima. Materi yang sebelumnya tidak dia mengerti dan ditanyakan, menjadi dipahami setelah mendapatkan penjelasan. Model penjelasan yang digunakan secara lisan kepada pelajar guna mencapai tujuan pembelajaran tertentu (Arifin, 2018).

Berdasarkan cerita di atas peneliti dapat disimpulkan bahwa nilai-nilai pendidikan dan standar proses dalam QS. Al-Kahfi yang bisa menjadi pelajaran bahwa antara guru dengan siswa harus memberikan kerjasama yang baik, siswa harus mampu bersabar sampai ada penjelasan dari seorang guru, sehingga mampu menciptakan aktivitas yang efektif dan efisien dalam belajar.

\section{KESIMPULAN DAN IMPLIKASI}

\section{Kesimpulan}

Metode pendidikan anak yang disampaikan Luqman dalam mendidik anak adalah metode suri tauladan. Luqman berwasiat kepada anaknya selalu memberikan contohcontoh langsung yang dilakukan oleh Luqman yakni dengan perbuatan nyata yang diperlihatkan (dicontohkan) kepada anaknya. Adapun nilai pendidikan dalam QS. Luqman ayat 12-19 adalah: (1) Pendidikan ketauhidan; (2) Pendidikan berbakti kepada kedua orang tua; (3) Pendidikan disiplin dan taat terhadap hukum; (4) Pendidikan pribadi mandiri dan bertanggung jawab; dan (5) Pendidikan akhlaqul karimah.
Adapun nilai pendidikan dalam QS. Al-Kahfi ayat 60-82, yang mana dalam kisah Nabi Musa dan hamba Allah tersebut terdapat standar proses yaitu: (1) Nilai kesabaran dan tekat; (2) Nilai urgenitas menyiapkan bekal; (3) Sikap tawadhu'; dan (4) Nilai urgensi menjelaskan materi pelajaran.

\section{Implikasi}

Penelitian ini dapat diambil hikmah dan bisa diterapkan dalam proses belajar di sekolah. Dalam mentransmisikan materi pendidikan Islam pada siswa, materi pendidikan Islam dapat dijadikan titik fokus tersendiri dan dapat pula diintegrasikan dalam mata pelajaran lain di Sekolah. Adapun Hasil dari penelitian mampu memberikan implikasi, antara lain: (1) Implikasi terhadap pengembangan cara belajar dan mengajar di kelas; (2) Implikasi terhadap cara pandang guru terhadap siswa; dan (3) Implikasi terhadap pendidikan dan tenaga kependidikan.

\section{DAFTAR PUSTAKA}

Al-Maragi, A. M. (1992). Terjemah Tafsir AlMaragi 21. Semarang: Toha Putra Semarang.

Al-Qur'an dan Terjemahan. (2009). Bandung: PT Sigma Examedia Arkanleema.

Arifin, M. L. (2018). Nilai-Nilai Edukasi dalam Kisah Musa-Khidir dalam AlQur'an. Jurnal Dialektika, 8(1), 28-39.

Harahap, N. (2014). Penelitian Kepustakaan. Jurnal Iqra', 8(1), 68-73.

Muhadjir, N. (2000). Metodologi Penelitian Kualitatif. Yogyakarta: Rake Sarasin.

Rifa'i, M. N. (2012). Tafsir Ibnu Katsir. Depok: Gema Insani.

Sada, H. J. (2015). Konsep Pembentukan Kepribadian Anak dalam Perspektif AlQur'an (Surat Luqman Ayat 12-19). Al- 
Tadzkiyyah: Jurnal Pendidikan Islam, 6(1), Surin, B. (2012). ALKANZ Terjemah dan 253-272.

Tafsir Al-Qur'an. Bandung: Titian Ilmu.

Shihab, M. Q. (2006). Tafsir Al-Misbah, Pesan, Zuhaili, W. A. (2013). Tafsir Al-Wasith. Kesan, dan Keserasian Al-Qur'an 7. Jakarta: Gema Insan.

Jakarta: Lentera Hati. 